\title{
PENGARUH PEMBELAJARAN BLENDED LEARNING DI MASA PANDEMI COVID-19 TERHADAP MOTIVASI BELAJAR DAN PEMAHAMAN KONSEP PESERTA DIDIK
}

\author{
Baiq Rohmi Masban ${ }^{1^{*}}$ \\ ${ }^{1}$ SMA Negeri 1 Sakra, Jalan Sukarno Hatta, Sakra, Lombok Timur, NTB 83671, Indonesia. \\ * Coressponding Author. E-mail: baiqrohmimasban@gmail.com
}

Received: 6 April 2021

Accepted: 30 November 2021 Published: 30 November 2021

doi: $10.29303 /$ cep.v4i3.2583

\begin{abstract}
Abstrak
Pendidikan di Indonesia menjadi salah satu bidang yang terdampak akibat adanya pandemi Covid-19. Kebijakan social distancing menyebabkan pembelajaran luring harus dikurangi dan diganti dengan pembelajaran daring. Tetapi pembelajaran menggunakan media daring (Google Classroom) di SMA Negeri 1 Sakra ternyata membuat peserta didik menjadi kurang termotivasi untuk belajar. Kurangnya motivasi ini menyebabkan nilai ulangan peserta didik pada mata pelajaran kimia bisa dibilang sangat mengecewakan (sangat rendah). Penelitian ini bertujuan untuk mengetahui Pengaruh pembelajaran Blended learning Terhadap Motivasi Belajar dan Pemahaman Konsep Peserta Didik di SMA Negeri 1 Sakra dengan metode penelitian pre experiment dan rancangan penelitian one group pretestPosttest design. Subyek penelitian berjumlah 30 orang yaitu kelas XII MIPA1 SMA Negeri 1 Sakra Kabupaten Lombok Timur Provinsi Nusa Tenggara Barat yang menggunakan pembelajaran blended learning. Instrumen penelitian yang digunakan dalam penelitian ini adalah instrumen kuesioner untuk motivasi belajar dan instrumen tes berbentuk pilihan ganda untuk pemahaman konsep. Data yang diperoleh di uji menggunakan uji $\mathrm{N}$-Gain, dan diuji normalitas dan homogenitasnya. Penggunaan pembelajaran blended learning, meingkatkan motivasi belajar dari rata-rata 63.24 menjadi 81.16 dan hasil belajar meningkat dari 35.1 menjadi 75.6. Penggunaan pembelajaran blended learning, memberikan kontribusi sebesar $47 \%$ (Nilai $\mathrm{N}-$ Gain $=0.47$ ) terhadap peningkatan motivasi belajar peserta didik danmemberikan kontribusi sebesar $61 \%($ Nilai $\mathrm{N}-$ Gain $=0.61)$ terhadap peningkatan pemahaman konsep peserta didik di kelas XII MIPA1 SMA Negeri 1 Sakra. Data yang diperoleh berdistribusi normal dan homogen karena karena nilai $\mathrm{L}_{\text {hitung }}<\mathrm{L}_{\text {tabel }}$ dan $\mathrm{F}_{\text {hitung }}<\mathrm{F}_{\text {tabel}}$, sehingga $\mathrm{H}_{0}$ diterima pada taraf signifikansi $5 \%(\alpha=0.05)$.
\end{abstract}

Kata kunci : Blended learning, motivasi belajar, pemahaman konsep

\section{The Effect of Blended Learning During Covid-19 Pandemic on Learning Motivation and Students' Concept Understanding}

\begin{abstract}
Education in Indonesia is one of the areas affected by the Covid-19 pandemic. The social distancing policy causes offline learning to be reduced and replaced with online learning. But learning using online media (Google Classroom) at SMA Negeri 1 Sakra turned out to make students less motivated to learn. This lack of motivation causes student test scores in chemistry subjects to be arguably very disappointing (very low). This study aims to determine the effect of blended learning on learning motivation and students' concept understanding in SMA Negeri 1 Sakra using pre-experimental research methods and one group pretestposttest design. The research subjects were 30 people, namely class XII MIPAI SMA Negeri 1 Sakra, East Lombok Regency, West Nusa Tenggara Province using Blended learning. The research instrument used in this study was a questionnaire instrument for learning motivation and a multiple choice test instrument for concept understanding. The data obtained were tested using the N-Gain test, and tested for normality and homogeneity. The use of blended learning, increases learning motivation from an average of 63.24 to 81.16 and learning outcomes increase from
\end{abstract}




\section{Chemistry Education Practice, 4 (3), 2021 - 302}

Masban

35.1 to 75.6. The use of blended learning, contributed $47 \%(N$-Gain value $=0.47)$ to the increase in student learning motivation and contributed $61 \%(N$-Gain value $=0.61)$ to the increase in students' conceptual understanding in class XII MIPAI SMA Negeri 1 Sakra. The data obtained were normally distributed and homogeneous because because the value of $L_{\text {count }}<L_{\text {table }}$ and $F_{\text {count }}<F_{\text {table }}$, so that $H_{O}$ was accepted at the $5 \%$ significance level $(\alpha=0.05)$.

Keywords: Blended learning, learning motivation, conceptual understanding.

\section{PENDAHULUAN}

Sejak diumumkan oleh Presiden Joko Widodo mengenai kasus pertama Corona Virus Disease 2019 (Covid-19) pada awal Maret 2020 yang lalu, Indonesia kemudian dihadapkan pada masa pandemi. Sejak hari itu, jumlah kasus positif Corona semakin bertambah dari hari ke hari. Akibat dari pandemi Covid-19 ini, menyebabkan diterapkannya berbagai kebijakan untuk memutus mata rantai penyebaran virus Covid-19 di Indonesia. Upaya yang dilakukan oleh pemerintah di Indonesia salah satunya dengan menerapkan himbauan kepada masyarakat agar melakukan physical distancing yaitu himbauan untuk menjaga jarak diantara masyarakat, menjauhi aktivitas dalam segala bentuk kerumunan, perkumpulan, dan menghindari adanya pertemuan yang melibatkan banyak orang. Upaya tersebut ditujukan kepada masyarakat agar dapat dilakukan untuk memutus rantai penyebaran pandemi Covid-19 yang terjadi saat ini (Puspitasari, 2020).

Pendidikan di Indonesia pun menjadi salah satu bidang yang terdampak akibat adanya pandemi Covid-19 tersebut (Purwanto, dkk., 2020). Dengan adanya pembatasan interaksi, Kementerian Pendidikan di Indonesia juga mengeluarkan kebijakan yaitu dengan meliburkan sekolah dan mengganti proses Kegiatan Belajar Mengajar (KBM).

Keputusan Bersama 4 Menteri yaitu Menteri Pendidikan dan Kebudayaan, Menteri Agama, Menteri Kesehatan, dan Menteri Dalam Negeri yang dituangkan dalam Panduan Penyelenggaraan Pembelajaran Pada Tahun Ajaran 2020/2021 dan Tahun Akademik 2020/2021 di Masa Pandemi Corona Virus Disease 2019 (Covid19) menyatakan bahwa satuan pendidikan yang berada di daerah ZONA KUNING, ORANYE, DAN MERAH, dilarang melakukan proses pembelajaran tatap muka di satuan pendidikan dan tetap melanjutkan Belajar dari Rumah (BDR) sesuai dengan Surat Edaran Menteri Pendidikan dan Kebudayaan Nomor 4 Tahun 2020 tentang Pelaksanaan Kebijakan Pendidikan dalam Masa Darurat Penyebaran Corona Virus Disease 2019 (Covid-19) dan Surat Edaran Sekretaris Jenderal
Kementerian Pendidikan dan Kebudayaan Nomor 15 Tahun 2020 tentang Pedoman Penyelenggaraan Belajar dari Rumah dalam Masa Darurat Penyebaran Corona Virus Disease 2019 (Covid-19), Keputusan Direktur Jenderal Pendidikan Islam Nomor 2791 Tahun 2020 tentang Panduan Kurikulum Darurat pada Madrasah, Surat Edaran Direktur Jenderal Pendidikan Islam Nomor 657 Tahun 2020 tentang Upaya Pencegahan Penyebaran Covid19 di Lingkungan Perguruan Tinggi Keagamaan Islam (Kemdikbud, 2021).

Pembelajaran secara daring menjadi solusi kegiatan belajar mengajar tetap jalan di tengah pandemi corona (Gusty, dkk., 2020). Ditengah banyaknya pro-kontra terkait pembelajaran daring, ternyata juga terdapat berbagai hikmah bagi pendidikan di Indonesia. Diantaranya, peserta didik maupun guru dapat menguasai teknologi untuk menunjang pembelajaran secara online ini. Guru maupun peserta didik dituntut agar memiliki kemampuan dalam bidang teknologi pembelajaran (Siahaan, 2020). Penguasaan peserta didik maupun guru terhadap teknologi pembelajaran yang sangat bervariasi, menjadi tantangan tersendiri bagi mereka. Dengan adanya kebijakan Belajar Dari Rumah (BDR), maka mampu memaksa dan mempercepat mereka untuk menguasai teknologi pembelajaran secara digital sebagai suatu kebutuhan bagi mereka. Tuntutan kebutuhan tersebut, membuat mereka dapat mengetahui media online yang dapat menunjang sebagai pengganti pembelajaran di kelas secara langsung, tanpa mengurangi kualitas materi pembelajaran dan target pencapaian dalam pembelajaran.

Berbagai media pembelajaran jarak jauh pun dicoba dan digunakan. Sarana yang dapat digunakan sebagai media pembelajaran online antara lain, Google Classroom, e-Learning, Zoom, YouTube, maupun media sosial WhatsApp. Sarana-sarana tersebut dapat digunakan secara maksimal, sebagai media dalam melangsungkan pembelajaran seperti di kelas. Dengan menggunakan media online tersebut, maka secara tidak langsung 


\section{Chemistry Education Practice, 4 (3), 2021 - 303}

Masban

kemampuan menggunakan serta mengakses teknologi semakin dikuasai oleh peserta didik maupun guru (Puspitasari, 2020).

Google Classroom menjadi salah satu aplikasi yang menjadi pilihan utama banyak sekolah, universitas dan lembaga pendidikan lainnya di tengah pandemi corona saat ini. Karena para peserta kelas tidak lagi perlu keluar rumah untuk berinteraksi dan belajar di kelas (Alfina, 2020). Pembelajaran menggunakan media daring (Google Classroom) di SMA Negeri 1 Sakra ternyata membuat peserta didik menjadi kurang termotivasi untuk belajar. Kurangnya motivasi ini menyebabkan nilai ulangan peserta didik pada mata pelajaran kimia bisa dibilang sangat mengecewakan (sangat rendah). Jumlah peserta didik yang nilainya tidak mencapai KKM (tidak tuntas) mencapai $91,8 \%$.

Berdasarkan hal tersebut, peneliti mengambil kesimpulan kalau pembelajaran daring yang mereka jalani selama ini tidak terlalu efektif, terutama untuk pembelajaran yang terkait dengan hitungan seperti mata pelajaran Kimia yang peneliti ampu. Hal ini membuat peneliti mencoba untuk menerapkan pembelajaran yang menggabungkan pembelajaran daring dengan luring (Blended learning). Blended learning adalah sebuah kemudahan pembelajaran yang menggabungkan berbagai cara penyampaian, model pengajaran, dan gaya pembelajaran, memperkenalkan berbagai pilihan media dialog antara fasilitator dengan orang yang mendapat pengajaran (Noveandini \& Wulandari, 2020; Juliannisa, 2020). Blended learning juga sebagai sebuah kombinasi pengajaran langsung (face-to-face) dan pengajaran online, tapi lebih daripada itu sebagai elemen dari interaksi sosial (Sari, 2016).

Di masa Pandemi Covid-19, menuntut adanya perubahan sistem pembelajaran. Metode pembelajaran blended learning bisa dimanfaatkan menjadi sistem pembelajaran baru. Meskipun nantinya PSBB Covid-19 sudah normal, blended learning tetap bisa dilaksanakan. Menurut guru Sistem Informatika Universitas Mercu Buana (UMB) Andi Nugroho (2020), salah satu alternatif pembelajaran di masa pandemi Covid-19 adalah dengan blended learning. Blended learning merupakan salah satu model pembelajaran yang dapat diterapkan melalui penggunaan media berbasis TIK. Oleh karena itu peran pendidik dalam hal ini dituntut untuk menguasai teknik mencari informasi di Internet, menyajikan materi melalui web yang menarik dan diminati, melayani bimbingan dan komunikasi melalui internet, dan kecakapan lain yang diperlukan.
Pembelajaran Blended learning diharapkan mampu meningkatkan motivasi dan hasil belajar peserta didik di masa pandemi Covid-19 ini. Dengan demikian penelitian ini berjudul "Pengaruh Pembelajaran Blended learning di Masa Pandemi Covid-19 Terhadap Motivasi Belajar dan Pemahaman Konsep Peserta Didik Kelas XII MIPA1"

\section{METODE}

Jenis penelitian ini adalah quasi experiment atau eksperimen semu. Disain penelitian yang digunakan adalah one group pretestposttest design. Pada disain ini, observasi dilakukan sebanyak 2 kali yaitu sebelum eksperimen dan sesudah eksperimen. Observasi yang dilakukan sebelum eksperimen $\left(\mathrm{O}_{1}\right)$ yaitu kuesioner dan tes awal (pretest) untuk mengetahui motivasi belajar dan pemahaman konsep awal peserta didik sedangkan observasi sesudah eksperimen $\left(\mathrm{O}_{2}\right)$ yaitu kuesioner dan tes akhir (posttest) menggunakan instrumen tes yang sama seperti tes awal (pretest). Perbedaan antara $\mathrm{O}_{1}$ dan $\mathrm{O}_{2}$ yakni $\mathrm{O}_{2}-\mathrm{O}_{1}$ diasumsikan merupakan efek dari treatment atau eksperimen.

Untuk lebih jelasnya dapat dilihat pada tabel berikut:

Tabel 1. Disain penelitian

\begin{tabular}{ccc}
\hline Pretest & Treatment & Posttest \\
\hline $\mathrm{O}_{1}$ & $\mathrm{X}$ & $\mathrm{O}_{2}$ \\
\hline
\end{tabular}

Penelitian dilakukan di SMA Negeri 1 Sakra Lombok Timur Provinsi Nusa Tenggara Barat. Kelas yang dijadikan subyek penelitian adalah kelas XII MIPA 1 (30 orang).

Instrumen pengumpulan data yang digunakan adalah kuesioner dan tes pilihan ganda.

Kuesioner diberikan untuk mengetahui motivasi awal keadaan kelas sebelum menerapkan model pembelajaran Blended learning maupun setelah penerapan model pembelajaran tersebut. Untuk mengukur pemahaman konsep peserta didik, instrumen yang digunakan adalah soal tes berbentuk pilihan ganda. Soal bentuk pilihan ganda merupakan soal yang telah disediakan pilihan jawabannya (Depdiknas, 2008). Soal tes tersebut terdiri dari $25 \mathrm{soal} /$ pertanyaan. Masingmasing pertanyaan memiliki 5 opsi jawaban dengan pilihan jawaban terdiri dari satu jawaban benar dan sisanya sebagai pengecoh. Sebelum soal digunakan, terlebih dahulu soal tersebut diuji validitas dan reliabilitasnya. Uji validitas digunakan untuk mengukur sah, atau valid 


\section{Chemistry Education Practice, 4 (3), 2021 - 304}

Masban

tidaknya suatu kuesioner (Ghozali, 2009). Sedangkan uji reliabilitas menurut Sugiarto dan Sitinjak (2006) menunjuk pada suatu pengertian bahwa instrumen yang digunakan dalam penelitian untuk memperoleh informasi yang digunakan dapat dipercaya sebagai alat pengumpulan data dan mampu mengungkap informasi yang sebenarnya dilapangan. Jumlah soal yang diuji validitas dan reliabilitasnya sebanyak 40 soal. Dari ke-40 soal tersebut terdapat 34 soal yang valid dan reliabel. Soal yang digunakan pada penelitian ini diambil dari soal yang sudah teruji validitas dan reliabilitasnya.

Pengumpulan data untuk instrumen kuesioner motivasi belajar dilakukan melalui Google Form. Data yang diperoleh kemudian dianalisis dengan menggunakan rumus:

$$
\mathrm{S}=\frac{\mathrm{R}}{\mathrm{N}} \times 100
$$

Keterangan :

$\mathrm{S}=$ skor yang dicapai

$\mathrm{R}=$ jumlah skor dari item atau soal yang benar

$\mathrm{N}$ = banyaknya data yang diambil

Untuk mengukur motivasi belajar peserta didikk uesioner yang digunakan memiliki lima alternatif jawaban yaitu: sangat setuju (SS), setuju (S), netral (N), kurang setuju (KS) dan tidak setuju (TS). Skor setiap alternatif jawaban pada pernyataan positif dan pernyataan negatif yang diberikan oleh responden adalah sebagai berkut:

Tabel 2. Skor alternatif jawaban kuesioner

\begin{tabular}{|c|c|c|c|}
\hline \multicolumn{2}{|c|}{ Pernyataan positif } & \multicolumn{2}{|c|}{ Pernyataan negatif } \\
\hline $\begin{array}{c}\text { Alternatif } \\
\text { jawaban }\end{array}$ & skor & $\begin{array}{c}\text { Alternatif } \\
\text { jawaban }\end{array}$ & skor \\
\hline Sangat setuju (SS) & 5 & $\begin{array}{l}\text { Sangat setuju } \\
\text { (SS) }\end{array}$ & 1 \\
\hline Setuju (S) & 4 & Setuju (S) & 2 \\
\hline Netral (N), & 3 & Netral $(\mathrm{N})$ & 3 \\
\hline $\begin{array}{l}\text { Kurang setuju } \\
\text { (KS) }\end{array}$ & 2 & $\begin{array}{c}\text { Kurang setuju } \\
\text { (KS) }\end{array}$ & 4 \\
\hline Tidak setuju (TS) & 1 & $\begin{array}{l}\text { Tidak setuju } \\
\text { (TS) }\end{array}$ & 5 \\
\hline
\end{tabular}

Kuesioner motivasi belajar terdiri dari 15 soal dengan 13 soal pernyataan positif (vafourable) dan 2 soal pernyataan negatif (unvafourable). Jumlah soal yang diuji validitas dan reliabilitasnya sebanyak 25 soal. Dari ke-40 soal tersebut terdapat 19 soal yang valid dan reliabel. Soal yang digunakan pada penelitian ini diambil dari soal yang sudah teruji validitas dan reliabilitasnya.
Tabel 3. Indikator Motivasi Belajar

\begin{tabular}{|c|c|c|c|}
\hline Variabel & Indikator & No. butir & $\begin{array}{l}\text { Jmlh } \\
\text { butir }\end{array}$ \\
\hline Motivasi & a. Mengerjakan tugas & 1,2 & 2 \\
\hline \multirow[t]{6}{*}{ belajar } & $\begin{array}{l}\text { b. Ulet dalam } \\
\text { menghadapi kesulitan }\end{array}$ & 3,4 & 2 \\
\hline & $\begin{array}{l}\text { c. Minat dalam masalah- } \\
\text { masalah belajar }\end{array}$ & $5,6,7$ & 3 \\
\hline & $\begin{array}{l}\text { d. Lebih senang bekerja } \\
\text { mandiri }\end{array}$ & 8,9 & 2 \\
\hline & $\begin{array}{l}\text { e. Cepat bosan pada } \\
\text { tugas-tugas rutin }\end{array}$ & $10^{*}, 11$ & 2 \\
\hline & $\begin{array}{l}\text { f. Dapat mempertahan- } \\
\text { kan pendapatnya }\end{array}$ & 12,13 & 2 \\
\hline & $\begin{array}{l}\text { g. Tidak mudah } \\
\text { melepaskan apa yang } \\
\text { diyakini }\end{array}$ & $14,15^{*}$ & 2 \\
\hline
\end{tabular}

Pengumpulan data untuk tes dilakukan dengan memberikan soal sebelum dilakukan perlakuan (pretest) dan setelaj dilakukan perlakuan (Posttest). Tes pada saat pretest dan Posttest dengan jumlah sebanyak 25 butir soal dengan soal yang sama.

Proses penskoran atau penilaian terhadap jawaban testee (yang diuji) dilakukan dengan menggunakan rumus berikut:

$$
S=\frac{B}{N} \times 100
$$

Keterangan

$\mathrm{S}=$ Skor

$\mathrm{B}=$ Jumlah item yang dijawab benar

$\mathrm{N}$ = Jumlah item soal pilihan ganda

Selanjutnya, nilai yang diperoleh dianalisis untuk mengetahui ketercapaian ketuntasan peserta didik. Untuk memutuskan seorang peserta didik sudah tuntas atau belum, maka nilai peserta didik harus dibandingkan dengan kriteria ketuntasan minimal (KKM) yang telah ditentukan/sepakati oleh satuan pendidikan. Nilai KKM untuk semua mata pelajaran di SMA Negeri 1 Sakra dibuat sama yaitu 70 untuk kelas semua kelas X.

Peserta didik disebut tuntas apabila nilai yang dipreoleh lebih besar atau sama dengan KKM ( $\mathrm{x} \geq \mathrm{KKM}$ ), dan peserta didik disebut tidak tuntas apabila nilai yang dipreoleh lebih besar atau sama dengan KKM ( $<$ KKM).

Untuk mendapatkan data yang relevan dari hasil kuesioner yang diberikan sebelum dan sesudah perlakuan serta data yang diperoleh dari pretest dan juga Posttest pada penelitian kuantitatif digunakan uji N-Gain. Gain adalah selisih antara nilai Posttest dan pretest.

Uji normal Gain (N-Gain) ini dilakukan untuk mengetahui peningkatan motivasi belajar 


\section{Chemistry Education Practice, 4 (3), 2021 - 305}

Masban

peserta didik sebelum dan sesudah perlakuan serta peningkatan skor pretest dan Posttest.

Peningkatan tersebut dihitung dengan rumus $\mathrm{g}$ faktor (N-Gain) dengan rumus:

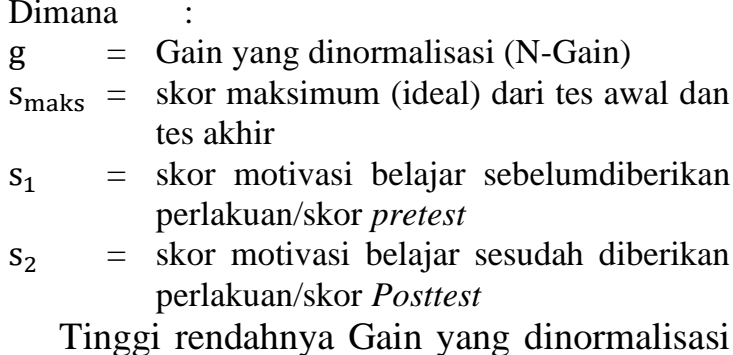

$$
g=\frac{S_{2}-S_{1}}{S_{\text {maks }}-S_{1}}
$$

) dapat diklasifikasikan sesuai Tabel 4 (Hake, 1999).

Tabel 4. Nilai dan kategori N-Gain

\begin{tabular}{cc}
\hline $\mathbf{N}-$ Gain & Kategori \\
\hline $\mathbf{g} \geq \mathbf{0 , 7}$ & Tinggi \\
$\mathbf{0 , 3} \leq \mathbf{g}<\mathbf{0 , 7}$ & Sedang \\
$\mathbf{g}<\mathbf{0 , 3}$ & Rendah \\
\hline
\end{tabular}

Nilai peserta didik yang telah terkumpul selanjutnya diuji normalitasnya. Pengujian normalitas adalah suatu analisis yang dilakukan untuk menguji apakah data berasal dari populasi yang berasal dari populasi yang berditribusi normal atau tidak. Uji normalitas dilakukan dengan menggunakan uji Liliefors karena sampel berukuran kurang dari 30. Pengujian dilakukan dengan membandingkan nilai Lhitung dan Ltabel dengan kiteria pengujian (Haniah, 2014):

- Terima $\mathrm{H}_{0}$ jika $\mathrm{L}_{\text {hitung }}<\mathrm{L}_{\text {tabel }}$; dan

- Tolak $\mathrm{H}_{0}$ jika $\mathrm{L}_{\text {hitung }}>\mathrm{L}_{\text {tabel }}$

Selain uji normalitas, dilakukan pula uji homogenitas untuk mengetahui apakah pupulasi memiliki varians yang homogen. Uji homogenitas hanya digunakan pada uji parametris yang menguji perbedaan antara kedua kelompok atau beberapa kelompok yang berbeda subjeknya atau sumber datanya (Hidayat, 2017).

Teknik yang digunakan untuk uji homogenitaspada penelitian ini adalah dengan uji Fisher, pada taraf signifikansi 0,05. Uji Fisher digunakan untuk menguji hanya pada 2 kelompok data. Pengujian dilakukan dengan membandingkan nilai $\mathrm{L}_{\text {hitung }}$ dan $\mathrm{L}_{\text {tabel }}$ dengan kiteria pengujian:

- Terima $\mathrm{H}_{0}$ jika $\mathrm{F}_{\text {hitung }}<\mathrm{F}_{\text {tabel }}$; dan

- Tolak $\mathrm{H}_{0}$ jika $\mathrm{F}_{\text {hitung }}>\mathrm{F}_{\text {tabel }}$

\section{HASIL DAN PEMBAHASAN}

Pembelajaran daring tidak terlalu diminati oleh peserta didik. Motivasi belajar peserta didik sangat rendah. Peneliti pernah bertanya kepada peserta didik, tentang apa saja yang mereka kerjakan selama mengikuti kegiatan pembelajaran daring (menggunakan Google Classroom), kesulitan apa saja yang mereka hadapi waktu mengikuti kegiatan pembelajaran daring (menggunakan Google Classroom) dan pembelajaran seperti apa yang mereka inginkan di masa pandemi Covid-19 ini.

Setelah memberikan pertanyaan tersebut, jawaban peserta didik hampir seragam. Beberapa jawaban peserta didik adalah sebagai berikut: 1) Selama belajar dari rumah, saya kebanyakan main $\mathrm{Bu}$ guru, belajarnya dikit aja. Terus saya kesulitan memahami materi kalau tidak tatap muka langsung. Nonton video ndak paham-paham Saya mengahrapkan adanya pembelajaran tatap muka walau hanya sekali sebulan; 2) Selama pembelajaran daring, saya hanya ngisi absen saja $\mathrm{Bu}$ guru, setelah itu rebahan sambil main game. Saya kesulitan memahami materi kalau gak tatap muka, apalagi materi hitungan; 3) Saya sering telat bangun $\mathrm{Bu}$ guru, kadang waktu mau belajar daring sering terkendala kuota. Materi susah masuk, nonton lewat YouTube kadang bikin ngantuk, ada tugas yang gak bisa dijawab bikin stress Bu guru; 4) Waktu pembelajaran daring saya cuma liat-lita materi saja $\mathrm{Bu}$, terus sulit memahami materi kalau belajar daring, apalagi materi yang rumusrumus. Kan kalau belajar sambil tatap muka bisa nanya langsung mana materi yang belum dipahami biar bisa dijelaskan ulang; 5) Kegiatan saya waktu belajar dari rumah ya ngisi absen sama liat materi. Kalau lagi belajar terus disuruh bantu-bantu sama orang tua, gak fokus belajar, gak ada kuota, kurang sinyal dan tidak terlalu mengerti sama materi yang dikasi sama Bapak/Ibu guru; 6) Saya pas belajar ya belajar, tapi emang lebih banyak main sama tidur. Sejak daring, saya jadi malas belajar. Kalaupun dikasi materi sama guru mapel, males bacanya; dan masih banyak jawaban senada lainnya.

Peneliti kemudian melakukan pembelajaran menggunakan blended learning yang menggabungkan pembelajaran daring dengan pembelajaran luring. Hasil yang diperoleh, adalah sebagai berikut:

\section{Motivasi Belajar}

Tujuan penelitian ini adalah untuk mengetahui pengaruh blended learning terhadap motivasi belajar peserta didik pada materi sel volta di SMA Negeri 1 Sakra. Dengan menggunakan pembelajaran blended learning, motivasi belajar peserta didik meningkat dengan sigifikan. Sebelum menggunakan pembelajaran 
blended learning, rata-rata motivasi belajar peserta didik berada pada nilai 63.24. Setelah menggunakan pembelajaran blended learning, ratarata motivasi belajar peserta didik meningkat menjadi 81.16. Rata-rata pemahaman konsep peserta didik dapat dilihat pada gambar 1 .

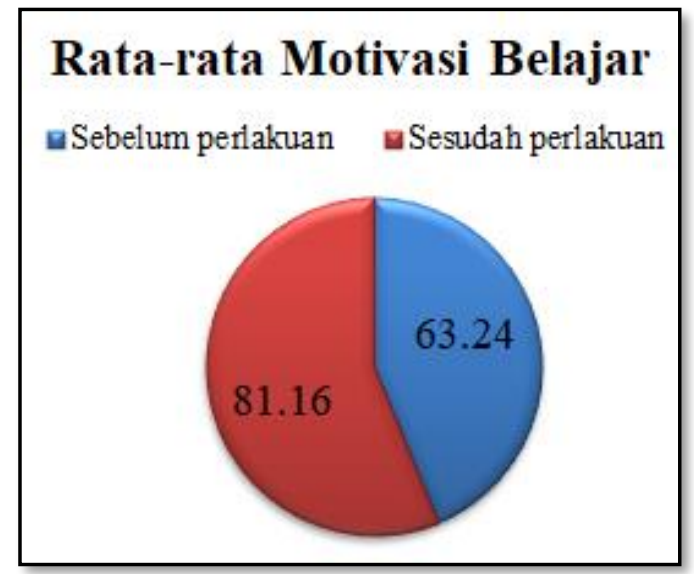

Gambar 1. Grafik Rata-rata Motivasi Belajar

Kategori motivasi belajar peserta didik sebelum dan sesudah penggunaan pembelajaran blended learning terlihat semakin bagus. Sebelum menggunakan pembelajaran blended learning jumlah peserta didik yang memiliki motivasi dengan kategori "Kurang" sebanyak 6 orang (20.00\%), jumlah peserta didik yang memiliki motivasi dengan kategori "Cukup" sebanyak 11 orang (36.67\%), jumlah peserta didik yang memiliki motivasi dengan kategori "Baik" sebanyak 11 orang $(36.67 \%)$ dan jumlah peserta didik yang memiliki motivasi dengan kategori "Sangat Baik" sebanyak 2 orang (6.67\%). Setelah menggunakan pembelajaran blended learning, sudah tidak ada lagi peserta didik yang memiliki motivasi dengan kategori "Kurang", jumlah peserta didik yang memiliki motivasi dengan kategori "Cukup" sebanyak 11 orang (36.67\%), jumlah peserta didik yang memiliki motivasi dengan kategori "Baik" sebanyak 11 orang (36.67\%) dan jumlah peserta didik yang memiliki motivasi dengan kategori "Sangat Baik" sebanyak meningkat menjadi 16 orang (53.33\%).

Persentase kategori motivasi belajar peserta didik dapat dilihat pada gambar 2 .

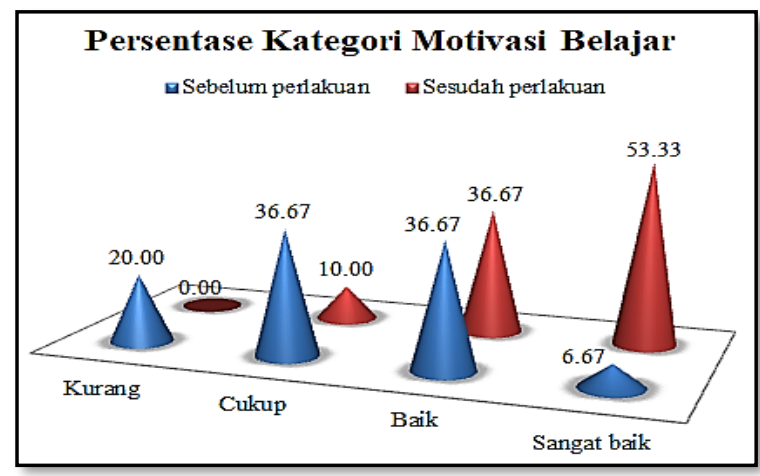

Gambar 2. Grafik Persentase Kategori Motivasi Belajar

Data motivasi belajar kemudian dianalisis dengan uji N-Gain. Uji N-Gain dilakukan untuk mengetahui adanya peningkatan motivasi belajar peserta didik setelah pembelajaran dilakukan peneliti. Uji NGain bisa memberikan gambaran umum peningkatan skor hasil pembelajaran antara sebelum dan sesudah diterapkannya blended learning. Berdasarkan hasil perhitungan pada kelas eksperimen hampir semua peserta didik mengalami peningkatan hasil belajar. Hal ini ditunjukkan oleh nilai $\mathrm{N}$-Gain peserta didik. Sebanyak 6 orang pada kategori tinggi, 22 orang kategori sedang dan hanya 3 orang berkategori rendah. Nilai rata-rata $\mathrm{N}$-Gain peserta didik yang diperoleh sebesar 0.47 dengan kategori sedang. Sehingga bisa disimpulkan bahwa motivasi belajar peserta didik setelah diterapkan blended learning meningkat sebesar $47 \%$.

Peningkatan motivasi belajar menggunakan Blended Learning juga telah diteliti oleh Ayu Parawanti (2019) dengan penelitian yang berjudul "Pengaruh Pembelajaran Berbasis E-Learning Model Blended Learning terhadap Motivasi Belajar Mahasiswa Program Studi Pendidikan Agama Islam Negeri (IAIN) Parepare". Pada penelitian ini diperoleh kesimpulan bahwa 1) Pembelajaran berbasis e-learning model blended learning berada pada kategori sedang yaitu $79 \%$. 2) Motivasi belajar mahasiswa Program Studi Pendidikan agama Islam Fakultas Tarbiyah Institut Agama Islam Negeri Parepare berada pada kategori sedang yaitu 74.4\%. 3) Terdapat pengaruh signifikan pembelajaran berbasis elearning model blended learning terhadap motivasi belajar mahasiswa Program Studi Pendidikan agama Islam Fakultas Tarbiyah Institut Agama Islam Negeri Parepare, hal ini dibuktikan dengan persamaan regresi $\mathrm{Y}=3.679$ $+0.678 \mathrm{x}$, koefisien korelasi sebesar 0.710 dan 


\section{Chemistry Education Practice, 4 (3), 2021 - 307}

Masban

koefisien determinan sebesar 50.4\%. Artinya pembelajaran berbasis e-learning model blended learning memberikan pengaruh sebesar $50.4 \%$ terhadap motivasi belajar mahasiswa Program Studi Pendidikan agama Islam Fakultas Tarbiyah Institut Agama Islam Negeri Parepare

\section{Pemahaman Konsep}

Tujuan penelitian ini juga untuk mengetahui pengaruh blended learning terhadap pemahaman konsep peserta didik pada materi sel volta di SMA Negeri 1 Sakra. Dengan menggunakan pembelajaran blended learning, pemahaman konsep peserta didik meningkat dengan sigifikan. Sebelum menggunakan pembelajaran blended learning, rata-rata hasil pretest peserta didik berada pada nilai 35.1 . Setelah menggunakan pembelajaran blended learning, hasil posttest peserta didik meningkat menjadi 75.6. Rata-rata hasil belajar peserta didik dapat dilihat pada gambar berikut.

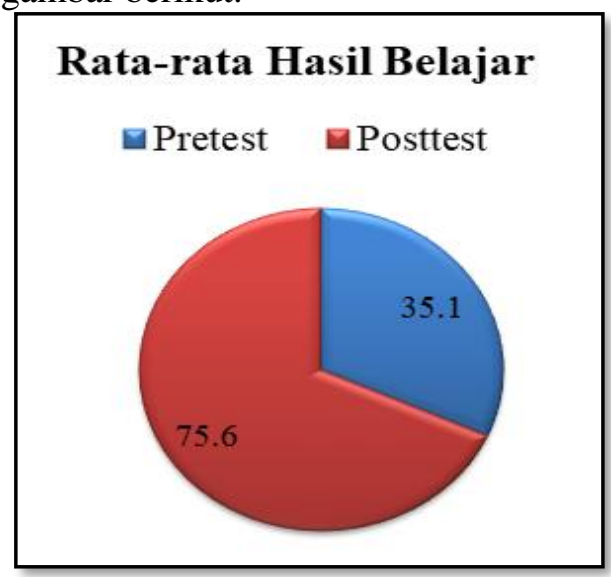

Gambar 3. Grafik Rata-rata Hasil Belajar

Tingkat ketuntasan peserta didik sebelum dan sesudah penggunaan pembelajaran blended learning terlihat semakin bagus. Sebelum menggunakan pembelajaran blended learning jumlah peserta didik yang "Tuntas" yaitu peserta didik nilaianya lebih besar atau sama dengan KKM (70) hanya 2 orang $(6.67 \%)$, sementara 28 orang $(93.33 \%)$ sisanya "Tidak tuntas" yaitu peserta didik yang nilainya di bawah KKM (70).

Setelah menggunakan pembelajaran blended learning, jumlah peserta didik yang "Tuntas" yaitu peserta didik nilaianya lebih besar atau sama dengan KKM (70) meningkat menjadi 23 orang (76.67\%), sementara peserta didik yang "Tidak tuntas" yaitu peserta didik yang nilainya di bawah KKM (70) berkurang menjadi 7 orang (23.33\%). Persentase ketercapaian ketuntasan peserta didik dapat dilihat pada gambar 4 .

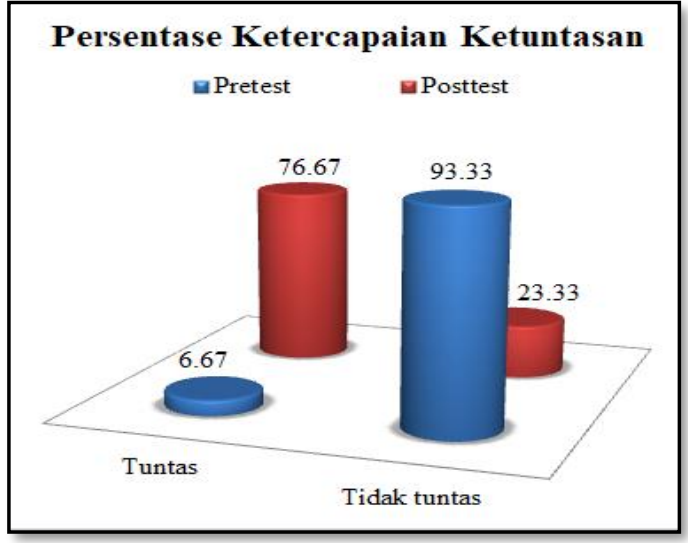

Gambar 4. Grafik persentase ketercapaian ketuntasan

Data pemahaman konsep kemudian dianalisis dengan uji $\mathrm{N}$-Gain, normalitas dan homogenitas. Uji N-Gain dilakukan untuk mengetahui adanya peningkatan pemahaman atau penguasaan konsep peserta didik setelah pembelajaran dilakukan peneliti. Uji N-Gain bisa memberikan gambaran umum peningkatan skor hasil pembelajaran antara sebelum dan sesudah diterapkannya blended learning. Berdasarkan hasil perhitungan pada kelas eksperimen hampir semua peserta didik mengalami peningkatan hasil belajar.

Hal ini ditunjukkan oleh nilai $\mathrm{N}$-Gain peserta didik. Sebanyak 12 orang pada kategori tinggi, 17 orang kategori sedang dan hanya 2 orang berkategori rendah. Nilai rata-rata N-Gain peserta didik yang diperoleh sebesar 0.61 dengan kategori sedang. Sehingga bisa disimpulkan bahwa pemahaman konsep peserta didik setelah diterapkan blended learning meningkat sebesar $61 \%$.

Peningkatan motivasi belajar dan hasil belajar menggunakan Blended Learning juga telah diteliti oleh Sjukur (2012) dengan judul "Pengaruh Blended Learning terhadap Motivasi Belajar dan Hasil Belajar Siswa Tingkat SMK". Pada penelitian ini diperoleh kesimpulan bahwa terdapat perbedaan motivasi belajar antara siswa yang diajarpembelajaran blended learning dibandingkan siswa yang diajar pembelajaran konvensional dengan nilai sig. 0,012 dengan rata-rata 4,74 dan terdapat perbedaan hasil belajar dengan nilai sig. 0,000 denganrata-rata 13,39. Di samping itu, ada peningkatan motivasi belajar siswa akibat penerapan pembelajaran blended learning dengan nilai sig. 0,000 ratarata peningkatan 13,55 dan ada peningkatan hasil belajar siswa dengan nilai sig. 0,000 ratarata peningkatan 38,23

Motivasi belajar dan pemahaman konsep peserta didik masih bisa ditingkatkan 


\section{Chemistry Education Practice, 4 (3), 2021 - 308}

Masban

dengan melakukan beberapa perbaikan, misalnya menyiapkan materi pembelajaran daring yang interaktif, menyiapkan lembar kerja yang lebih baik lagi yang dapat membimbing peserta didik lebih mendalami konsep. Waktu yang cukup lama dapat memfasilitasi diskusi lebih baik lagi sehingga semua permasalahan yang dialami peserta didik.

Berdasarkan hasil perhitungan uji normalitas dan homogenitas dapat disimpulkan bahwa data hasil penelitian yang diperoleh berdistribusi normal dan homogen. Uji normalitas untuk data instrumen (kuesioner dan tes) menggunakan uji Liliefors (uji L). Nilai L hitung untuk data kuesioner motivasi belajar peserta didik adalah kuesioner awal (-0.023), kuesioner akhir (0.003), Gain (0.002) dan N-Gain (-0.078). Nilai

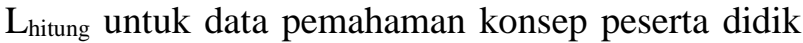
adalah pretest (0.017), postest (-0.072), Gain (0.012) dan N-Gain (-0.070) dengan nilai Ltabel sebesar 0,161. Karena $\mathrm{L}_{\text {hitung }}<\mathrm{L}_{\text {tabel }}$, maka $\mathrm{H}_{0}$ (sampel berasal dari populasi berdistribusi normal) diterima pada taraf signifikansi 5\% $(\alpha=0,05)$. Sedangkan untuk uji homogenitas menggunakan uji Fisher (uji F). Hasil uji $F$ yang diperoleh menunjukan bahwa $F_{\text {hitung }}<\mathrm{F}_{\text {tabel }}$. Dengan demikian $\mathrm{H}_{0}$ (varians 1 sama dengan varians 2 atau homogen) diterima pada taraf signifikansi 5\% $(\alpha=0.05)$.

\section{SIMPULAN}

Berdasarkan hasil penelitian dapat disimpulkan bahwa penggunaan pembelajaran blended learning, dapat meningkatkan motivasi belajar dan pemahaman konsep peserta didik. Ratarata motivasi belajar awal peserta didik berada pada nilai 63.24. Setelah menggunakan pembelajaran blended learning, rata-rata motivasi belajar peserta didik meningkat menjadi 81.16. Rata-rata hasil pretest peserta didik berada pada nilai 35.1 dengan jumlah peserta didik yang "Tuntas" hanya 2 orang (6.67\%), sementara 28 orang $(93.33 \%)$ sisanya "Tidak tuntas". Setelah menggunakan pembelajaran blended learning, hasil posttest peserta didik meningkat menjadi 75.6. dengan jumlah peserta didik yang "Tuntas" meningkat menjadi 23 orang (76.67\%), sementara peserta didik yang "Tidak tuntas" berkurang menjadi 7 orang $(23.33 \%)$.

Peningkatan motivasi belajar dan pemahaman konsep peserta didik juga terlihat dari hasil uji N-Gain. Untuk motivasi belajar, penggunaan pembelajaran blended learning, dapat memberikan kontribusi sebesar 47\% (Nilai N-Gain $=0.47$ ) terhadap peningkatan motivasi belajar peserta didik. Untuk pemahaman konsep, penggunaan pembelajaran blended learning, dapat memberikan kontribusi sebesar 61\% (Nilai N-Gain
$=0.61)$ terhadap peningkatan pemahaman konsep peserta didik.

\section{DAFTAR PUSTAKA}

Alfina, O. (2020). Penerapan lms-google classroom dalam pembelajaran daring selama pandemi covid-19. Majalah Ilmiah Methoda, 10(1), 38-46.

Ghozali, I. (2009). Aplikasi Analisis Multivariate dengan Program SPSS. Semarang: UNDIP.

Gusty, S., Nurmiati, N., Muliana, M., Sulaiman, O. K., Ginantra, N. L. W. S. R., Manuhutu, M. A., ... \& Warella, S. Y. (2020). Belajar Mandiri: Pembelajaran Daring di Tengah Pandemi Covid-19. Yayasan Kita Menulis.

Hake, R. (1999). Analyzing Changel Gain Score. Indiana: Indiana University.

Haniah, N. (2014). Uji normalitas dengan metode liliefors.

Juliannisa, I. A. (2020). Peningkatan Pembelajaran Melalui Situs Media Online dengan Metode Blended Learning Pada Masyarakat Desa Bojongcae. Journal of Dedicators Community, 4(1), 68-78.

Kemendikbud, R. I. (2020). Panduan Penyelenggaraan Pembelajaran pada Tahun Ajaran dan Tahun Akademik Baru di Masa Pandemi Covid-19: Satuan Pendidikan di Zona Kuning. Oranye dan Merah Dilarang Melakukan Pembelajaran Tatap Muka.

Nasional, D. P. (2008). Panduan analisis butir soal. Jakarta: Depdiknas.

Noveandini, R., \& Wulandari, M. S. (2010). Pemanfaatan media pembelajaran secara online (e-learning) bagi wanita karir dalam upaya meningkatkan efektivitas dan fleksibilitas Pemantauan Kegiatan Belajar Anak Siswa/i Sekolah Dasar. In Seminar Nasional Aplikasi Teknologi Informasi (SNATI).

Parawanti, A. (2019). Pengaruh Pembelajaran Berbasis E-Learning Model Blended Learning Terhadap Motivasi Belajar Mahasiswa Program Studi Pendidikan Agama Islam Negeri (IAIN) Parepare (Doctoral dissertation, IAIN Parepare).

Purwanto, A., Pramono, R., Asbari, M., Hyun, C. C., Wijayanti, L. M., \& Putri, R. S. (2020). Studi eksploratif dampak pandemi COVID-19 terhadap proses pembelajaran online di sekolah 
Chemistry Education Practice, 4 (3), 2021 - 309

Masban

dasar. EduPsyCouns: Journal of Education, Psychology and Counseling, 2(1), 1-12.

Puspitasari, R. (2020). Hikmah pandemi Covid-19 bagi pendidikan di Indonesia. Institut Agama Islam Negeri Surakarta.

Sari, M. (2016). Blended learning, model pembelajaran abad ke-21 di perguruan tinggi. Ta'dib, 17(2), 126-136.

Siahaan, M. (2020). Dampak pandemi Covid-19 terhadap dunia pendidikan. Dampak Pandemi Covid-19 Terhadap Dunia Pendidikan, 20(2).

Sitinjak, T. J. (2006). LISREL. Yogyakarta: Graha Ilmu.

Sjukur, S. B. (2012). Pengaruh blended learning terhadap motivasi belajar dan hasil belajar siswa di tingkat SMK. Jurnal pendidikan vokasi, 2(3). 